\title{
Poverty context in Proverbs 31:1-9: A Bena Tanzanian analysis for Transformational Leadership Training ${ }^{1}$
}

\author{
Peter Lechion Kimilike (Open University of TANZania, Dar Es \\ SALAAM)
}

\begin{abstract}
African biblical scholars have recognized the importance culture plays in biblical interpretation for Christianity's sacred texts to be authentically African. Cultural resources can liberate biblical interpretation from expert ideological dominance by creating critical reading masses in order to empower the community for transformation from the reality of multifaceted injustices such as poverty. Also the approach creates room for an equal fair dialogue with mainstream interpretive methods in biblical studies. This paper elaborates a model to the preceding aspects through transformative contextual exegetical interpretation of Prov 31:1-9 using the holistic cultural context, of the Bena of Tanzania. The said setup akin to the ancient Israelite one is inherently life-giving and sustaining to potentially transform the well-being of humanity for sustainable development. The reading goes beyond a stance of pure self-interest by challenging the victims to become involved in the eradication of poverty in African communities, especially with respect to leadership.
\end{abstract}

KEYWORDS: African transformational interpretation; leadership; poverty; Proverbs; women; public service ethics; humanness training; resource mobilisation.

\section{A INTRODUCTION}

The need for a decent life removed from state of weakness, dependency and humiliation in traditional Africa was and is still "fundamental to a new vision for a better Africa is the struggle to eradicate poverty. Not merely to alleviate it, but to eradicate it. Others may be content with alleviation or reduction of poverty. For Africans, our goal should be to eradicate poverty because it is

* Submitted: 13/11/2017; peer-reviewed: 12/02/2018; accepted: 01/03/2018. Peter Lechion Kimilike, "Poverty context in Proverbs 31:1-9: A Bena Tanzanian analysis for Transformational Leadership Training," OTE 31 no. 1 (2018): 135-163. DOI: https://doi.org/10.17159/2312-3621/2018/v31n1a8

1 This paper is a revised version of a shorter version presented at the annual conference of the Old Testament Society of South Africa, hosted by the University of Pretoria, 6-8 September 2017. 
noble, and it is the right course to chart and pursue." 2 Thus contemporary discussions for innovative effective methods of tackling and uprooting such an injustice become important and crucial initiatives. For biblical scholars the project implies recognition and mobilization of relevant resources for biblical interpretation. In the African context it means taking on board their culture that is akin to the ancient Israelite one as a means to re-reading the sacred texts to bring forth a liberating and empowering interpretation that can transform the community. Such a contribution goes beyond the ongoing debate attempting to inquire into Christianity's equivocal understanding of poverty and transmission of the same over generations which in Africa seems to have hurt, weakened, and failed to advance the quality of people's lives.

In light of the above this paper tries to discover the patterns of transformational leadership training behaviours in Prov 31:1-9, subsequently exemplifying its practicality in eradication of poverty in modern social setting. As a result the textual analysis highlights key transformational leadership patterns: capability of providing new vision, awareness creation among people with the vision, and resources mobilization and commitment to the realization of the vision. Hence, the objectives of this paper include an anthropological revisit of the Bena Tanzanian transformational context, biblical textual analysis and identification of the suggested transformative leadership training patterns relevant to contemporary Tanzania and Africa at large. In respect to the objectives the African transformational hermeneutic uses an African folklorist permeated contextual oriented approach integrating biblical exegetical and social anthropological option. The underlying theoretical framework is based on Levy's second-order planned change theory about creating a new way of seeing things completely requiring new learning that involves a nonlinear progression, a transformation from one state to another. The aim being to qualitatively enable the individual and community to behave, think, or feel differently toward enhancing their livelihood and life. ${ }^{3}$

\section{B BENA TANZANIAN VIS-À-VIS THE ISRAELITE TRANSFORMATIONAL CONTEXT AND THE CHALLENGE OF POVERTY}

Foremost, through the use of social anthropological methods a comparison has been made by scholars between the OT Proverbs and African proverbs indicating the presence of their similarities based on human experiences and God's inspiration. The latter are exemplified hereunder from the Bena ethnic.

2 Samuel M. Kobia, The Courage to Hope: A Challenge for Churches in Africa (Nairobi: Acton, 2003), 195.

3 Amir Levy, "Second-Order Planned Change: Definition and Conceptualization," ODyn 15/1 (1986): 5-17, 19-23. 
The uniqueness of the Bena a Bantu ethnic context is its world view based on strong cultural traditions with vibrant beliefs and customs. Its uniqueness is due to its geographical location of being surrounded by powerful warrior Bantu ethnic groups of the Hehe to the north, Ngoni to the south and Sangu to the south-west. From the interethnic wars between the latter ethnics evolved a survival culture for the Bena as a response to the aggressive and oppressive cultures of its neighbours. In essence, the Bena 'uvwunu' (ubuntu), namely, humanness abhors any sort of fighting because it is a threat to life. As a result their culture is kind of pacifist orientation with very strong peace, tranquillity and uniting elements within it that are fundamental in order to guarantee society's peaceful holistic existence. However, with a closer look they appear to be more or less indirectly separatist in tendency since they do not allow outsiders to enter and become part and parcel of the ethnic inner circles unless certain ritualistic processes have been performed and adhered to conventionally. ${ }^{4}$

Similar to the above is the geographical location of the Israelite nation that was situated between the big warrior nations of Egypt, Assyria and Persia. As a result, this land was a meeting place and battleground between the empires of Egypt to the West and Babylon and Persia to the East. The implication of the precarious situation group survival must have been of primary importance facing the Israelites most of the time. ${ }^{5}$ The group survival culture of the Hebrews was shaped by those they had contact with. As a result the OT essentially gives a unique survival picture of

... a story of a small band of people (Hebrews) - a people who obviously knew much suffering through conquest by surrounding tribes. Through the power of remarkable spiritual determination to forge cohesion and carve a distinctive identity, they succeeded in liberating themselves. They experienced this power as the children of Yahweh, their only God, who was there almost exclusively for them and was personalized as such. They experienced God primarily through the lens of communal identity, so that whatever did not serve this goal was either eliminated from the story or made subservient to it (emphasis is mine). ${ }^{6}$

4 Judah Bernard Matata Kiwovele, Malezi na Elimu ya Kiinjili katika Nchi Inayoendelea Tanzania: Mchango wa Mazungumzo ya Tamaduni Mbalimbali za Makanisa ya Kiinjili (Arusha: Makumira Publications, 2011), 71-72. Cf. Seth Nyagava, A History of the Bena to 1914 (Songea: Peramiho Printing Press, 2000), 3. Cf. Johanna Eggert, Njia Ndefu ya Shule Kuanzia katika Nyanda za Juu Kusini (Halle: Propstei Halle-Naumburg, 2004), 10, 13.

5 John H. Otwell, And Sarah Laughed: The Status of Women in the Old Testament (Philadelphia: Westminster, 1977), 40.

6 Laurenti Magesa, Anatomy of Inculturation: Transforming the Church in Africa (Maryknoll: Orbis Books, 2004), 3. 
Some of the uniting visible cultural elements concern taboos and totems which form the identities of family, clans and kinships as physical institutional expressions of collective conscience. Their essence is unity, making them neither exchangeable nor convertible. For the Bena ethnic taboos are linked to the concept of parent-child relationship which once established is permanent, cannot be bought or sold. The fidelity to the traditions and customs is the essence of taboo and totem and non-adherence is deemed abominable and a curse to the parents, ancestors and society. This cultural aspect is very significant because is a kind of an engaging standard to accept or reject changes in development, especially, those weakening the family bonds which are essential and critical to the survival of the individual and community in social, political, religious and economic terms. ${ }^{7}$ Such a background makes it very difficult to convert the Bena to new changes and appear conservative in times of changing values.

The above described aspects are closely related to the interactions between Israel and their neighbouring nations as described in the OT that emphasized the differences between their cultures, heritage, and general ways of life. One of those distinctions was the observance of consumption taboos. Israelites did not eat pork products - a practice consistent with Israelite identity. Also, the circumcision of the Israelites was a religious rite intended to mark the beginning of covenant solidarity for Abraham's descendants rather than describing the historical origins of the procedure, self-identity and depth of emotion involved in this ethnic tradition (Gen 15; Gen 17; Judg 14:3; 15:18; 1 Sam 14:6; 17:26, 36; 31:4; 2 Sam 1:20; 1 Chr 10:4).

Another cultural factor is the well-established work ethic of selfreliance. The Bena take work ethic seriously to the level of parents in one's adult life. They say "iligimilo ni nyengo ye dado nu nyoko" (lit. "The hoe and the cutlass are your father and mother"). Farming tools represent work that can keep one's life just like the parents do to their children making training on work an essential element in the upbringing of children. When the latter err, the tradition forbids disciplining by beating or use of abusive language instead a piece of work is to be given. They say "umwana uwungilage iligimilo sivaviwungila ulubiki" (lit. teach the child using the hoe not a stick). Or say ironically "ulubiki lwave lwi wulanidza luhala imbunda yaliyilutila uluhala" (lit. If the stick is a good teacher then the donkey would be a genious). This upbringing stems from their understanding that life is an unending challenging contest. Hence the upbringing focuses more on equipping its members with a high level of awareness of values and ability for assessment and critical reflection humanness so that they live life well. The cultural informal education and training help them to understand both the meaning of being poor and the

7 Cf. Kiwovele, Malezi na Elimu, 24-25, 73. 
means to confront challenging and changing conditions that produce destructive environment in the community. ${ }^{8}$

Work is considered to have a moral effect both on the individual and society. Hard working character earned them the ethnic name Bena which means "harvester" of finger millet their staple food replaced currently by maize. Farming of agricultural food crops is the main stay of their affectionate socio-economy. The agriculturally-based socio-economic system makes land the most treasured possession of the family, clan and kinship in all its aspects including environmental conservation. In fact, the farming vocation has made the Bena to spread throughout Tanzania wherever there is fertile arable land whereby once settled they establish their separate villages, use their ethnic language and marry among themselves. Consequently, the ethic of hard work and of opposition to parasitism embedded itself in Tanzania's Ujamaa ideology giving it an African identity. ${ }^{9}$

The Israelite work ethic is closer to the above discussed Bena approach towards self-reliance of the individual through the community (Gen 1:26-31; 2:5-8, 15-17; Prov 31:10-31; Ruth 2:1; Ruth 3:11). Davis, using an agrarian reading of the Bible, concretely observes that

... the biblical writers recognise that careful practical work is the best expression of our freedom and safeguard of our sanity. In a healthy society, such work is the means most consistently available for people to practice holiness of life, to imitate God's enabling and sustaining care for the world ${ }^{10}$ (cf. Prov 3:19).

Hence such a self-reliant economic system can be equated to an economy of sufficiency that has enough for everyone and gives the society a spirit of generosity ${ }^{11}$ (Exod 36:2; Eccl 5:9) based on God's attribute of abundance (Ps 36:7-9). ${ }^{12}$

8 Cf. Kiwovele, Malezi na Elimu, 23-24, 63-66, 82-84. Cf. Ndembwela H. Ngunangwa, "The Content of the Indigenous Curriculum of Education: Case Study: The School (of Aristocracy) (Vanyikongo) Among the Wabena of Tanzania" (PhD Thesis, Pittsburgh University, 1986) for more extensive details.

9 Ali A. Mazrui and Alamin M. Mazrui, Swahili State and Society: The Political Economy of an African Language (Nairobi: East African Education Publishers, 1995), 123.

10 Ellen F. Davis, Scripture, Culture and Agriculture: An Agrarian Reading of the Bible (New York: Cambridge University Press, 2009), 145.

11 Lechion P. Kimilike, Poverty in the Book of Proverbs: An African Transformational Hermeneutic of Proverbs on Poverty (New York: Peter Lang, 2008), 111, 137.

12 Lechion P. Kimilike, "After God Creates, Humankind Recreates: Reflections on the Teaching on Work as Contained in the Hebrew Bible and African Proverbs," AfTJ 29/2 (2006): 4-21. 
In that respect educational systems are goal-oriented in both traditions including Bena ethnic and ancient Israelite. The OT incorporates the Israelite society's established norms, values and practices as essential facets of sustainable character development that helped to shape both personal and community identity because training targets not merely financial achievement ${ }^{13}$ and the centrality of economic prosperity. ${ }^{14}$

Training is a consistent, successful and forward-looking principle of life, which stimulates the internal potential of one's intellectual and psychological aspects to dynamically develop and contribute to the enhancement of higher living standards. In this case Proverbs 13:18 deals with ideas concerning the creating of social capital by orientating ancient Israelite training institutions correctly in the battle to overcome poverty. ${ }^{15}$

The Bena traditional religion believes in one god (or God) called nguluvi, the creator who also deals with major episodes, and spirits of ancestors called misoka, who deal with affairs of individuals. ${ }^{16}$ The Bena culture like other African ethnics classify offences into; anti-social acts which, once committed, require redress through the payment of fines (e.g. the penalty for adultery is a payment of three cows); and anti-religious acts (e.g. doing things which are forbidden by religion called mudzilo in Bena language), the punishments for which are variable consequences or disasters such as hunger and diseases, even death. Notably the social and religious aspects of problems are holistically perceived as results of disobedience to God or within the family or disharmony in relationships or evil acts against God or between families, clan, kinship, or community. Justice and humanness deteriorate where there are such evil actions.

Therefore, justice is the foundation and source of humanness in society for protection of children and the weak against the social powers. ${ }^{17}$ It is the reason for the Bena's keeping of good relationships and unity among them as a key binding the community's existence and staying together. They believe that justice based on God of creation defends the righteous and judges those who err. Lack of justice causes injustice to flourish and its removal is through

${ }^{13}$ Crawford Howell Toy, A Critical and Exegetical Commentary on the Book of Proverbs (Edinburgh: T. \& T. Clark, 1899), 274. Also Edgar Jones, Proverbs and Ecclesiastes: Introduction and Commentary (London: SCM, 1961), 131.

${ }^{14}$ G. H. Wittenberg, The Lexical Context of the Terminology for the 'Poor' in the Book of Proverbs, Scriptura. S 2, (1986): 40-85. Also William McKane, Proverbs: A New Approach ( London: SCM, 1970), 457.

15 Kimilike, Poverty, 184.

16 W. Bryant Mumford, "Hehe-Bena-Sangu Peoples of East Africa," AmAn 36/2 (1934): 203-222.

17 Cf. Laurenti Magesa, African Religion: The Moral Traditions of Abundant Life (Nairobi: Paulines Publications Africa, 1998), 248. 
sacrifice. ${ }^{18}$ As a result they were never involved in raids against neighbouring Ngoni (Vapoma), Sangu and Hehe ethnics. ${ }^{19}$

The above aspect is similar to the Israelite orientation because concisely the OT context portrayal of God as Creator of humanity performs a social critical function. ${ }^{20}$ In the later is a means of communicating the divine reality about humanity and its criticism addresses violations of the ideal by certain members of the community, in order to avert disharmony in the cohesion, peace, stability and sustainable welfare of the entire society.

Respect of parents and elders is an obligation among the Bena, and even death cannot defer it. ${ }^{21}$ Direct references to unethical issues and shaming things are strictly avoided for fear of contaminating the minds and degrading the other folk in any sense. Among the grownups showing anger emotions is abhorred and considered a serious indication of childishness which can earn segregation from the adult meetings of any sort (cf. Prov 29:20). Therefore, the use of language to convey feelings is well-developed to the extent that outsiders may consider them to be hypocritical. ${ }^{22}$ The ethnic thinking framework is circular in nature implying what is spoken does necessary take literal meaning. In a sense always adults are expected to use inductive cumulative logical thinking to apprehend the message conveyed in discussions. ${ }^{23}$ Hence such a unique cultural context makes a creative, energetic, honesty, persistent idealistic and hardworking peasantry Bena society with an inbuilt pervasive responsible social conscience that works for constructive transforming change.

For detailed apparent worldview similarities of extended family, corporate feeling, moral optimism, thinking pattern, proverbial linguistic aspects, holistic worldview and pre-industrial economies based on subsistence agriculture between the African holistic world view and ancient Israelite worldview refer Kimilike's study. ${ }^{24}$ In my opinion, the described Bena context can provide a comparative practical performance context in interpreting the proverbs on the poor and poverty of the OT Proverbs in relation to the situation

18 Cf. Kiwovele, Malezi na Elimu, 57; cf. Julius K. Nyerere, Man and Development (Dar es Salaam: Oxford University Press, 1974), 85-86.

19 Cf. Nyagava, History of the Bena, 5.

20 Cf. Claus Westermann, Roots of Wisdom: The Oldest Proverbs of Israel and Other Peoples (Louisville: Westminster John Knox, 1995), 123-126. Cf. Habel C. Washington, Wealth and Poverty in the Instructions of Amenemope and Hebrew Proverbs (Atlanta: Scholars Press, 1994), 198.

21 Cf. Magesa, African Religion, 246.

22 Cf. Magesa, African Religion, 236. Cf. Marc J. Swartz, "Bases for Political Compliance in Bena Villages," in Political Anthropology, ed., Marc J. Swartz, Victor Turner, and Arthur Tuden (Chicago: Aldine, 1966), 89-108.

23 Cf. R. Sambuli Mosha, The Heartbeat of Indigenous Africa: A Study of the Chagga Educational System (New York: Garland, 2000), 14.

24 Cf. Kimilike, Poverty, 159-162. 
in Africa. However this approach does not in any way condemn the predominant Western interpretation on poverty as erroneous - rather it suits western protocols and expectations. ${ }^{25}$ In the later regard when reading the Western poverty interpretations as Africans are succinctly wondering at their lack of concern for African reality. ${ }^{26}$

Whose problems are they concerned with? What situation are they usually addressing? On behalf of whom do they speak? These and other similar remarks have arisen because the particular African communities did not perceive their hopes, concerns, faith and prayers reflected there. ${ }^{27}$

The above quests are wakeup calls for biblical scholars to develop documents that communicate to the African soul with respect to the reality facing it, particularly, the poverty challenge. One of those hermeneutic methods in its infancy is transformational approach supported by this paper.

\section{AN AFRICAN TRANSFORMATIONAL HERMENEUTIC OF BIBLICAL PROVERBS ON POVERTY REVIEWS}

The contemporary challenging economic situation, especially, the fight against poverty in Africa engages the academic biblical studies into the forefront at different levels of search for alternative interpretation strategies. ${ }^{28} \mathrm{~A}$ recent emerging alternative is the African transformational reading of poverty proverbs in the Book of Proverbs ${ }^{29}$ attracting interesting critical reviews. ${ }^{30}$

25 E.g. Mark Sneed, "The Class Culture in Proverbs: Eliminating Stereotypes," SJOT 10/2 (1996): 296-308.

26 Cf. Laurenti Magesa, Christian Ethics in Africa (Nairobi: Acton Publishers, 2002), 112-113.

27 Magesa, Christian Ethics, 156-157.

28 Cf. Knut Holter, "The Role of Historical-Critical Methodology in African Old Testament Studies," OTE 24/2 (2011): 377-389. Cf. Knut Holter, "The 'Poor' in Ancient Israel - and in Contemporary African Biblical Studies," MSt (2016): 209-221. 29 Cf. Kimilike, Poverty, 155-296. Cf. Lechion Peter Kimilike, “'The Poor Are Not Us!': An Exploration into the Transforming Possibilities of Old Testament and African Proverbs on Poverty," OTE 19/2 (2006): 418-428. Cf. Lechion Peter Kimilike, "Using African Proverbial Folklore to Understand the Holistic Poverty Eradication Framework in the Book of Proverbs," OTE 19/2 (2006): 405-417.

30 Cf. Thor Strandenes, "Missiology at the School of Mission and Theology, Stavanger," SMT 94/4 (2006): 469-492. Cf. Philip J. Nel, review of Poverty in the Book of Proverbs: African Transformational Hermeneutic of Proverbs on Poverty, by Lechion Peter Kimilike, online: https://www.bookreviews.org/ bookdetail.asp?TitleId =6641. Cf. Philip J. Nel, "Trends in Wisdom Research: A Perspective from the African Continent," Scriptura 111 (2012): 460-471. Cf. Katharine J. Dell, review of Poverty in the Book of Proverbs: African Transformational Hermeneutic of Proverbs on Poverty, by Lechion Peter Kimilike, JSOT 33/5 (2009): 156. Cf. Mark Sneed, review of Poverty in the Book of Proverbs: African Transformational Hermeneutic of 
Generally there is a positive recommendation to the African transformational approach's contribution to the OT scholarship. Notably Lucas has dedicated a section "An African Perspective" under the theological theme section "Wealthy and Poverty in Proverbs" in the recent marvellous "The Two Horizons Old Testament Commentary Series (THOTC)" of Book of Proverbs. ${ }^{31}$ His conclusion calls to attention the Gross National Product (GNP) versus Gross National Happiness $(\mathrm{GNH})$ debate by strongly suggesting that:

At a time when at least some people are questioning the priority of material wealth for human well-being the sages of ancient Israel have a relevant message with their relativising of material wealth and the primary place they give to the importance of spiritual and moral aspects of wisdom for the well-being of communities and human flourishing in them. Christians need to consider how this can be brought into the current market-place of ideas.

Kimilike's work is a reminder that while these ideas are discussed, there is an urgent need, in the West as well as in Africa and elsewhere, to engage in the day-to-day battle against poverty. ${ }^{32}$

A similar opinion was earlier raised by Nel's constructive critical review of transformational approach that:

The critical issues raised should not distract from the important contribution this study [transformational hermeneutic] makes, in particular by challenging traditional interpretations of Proverbs. The insistence of the author that the interpretation should be socialtransformative in a world with a dire need for direction and vision obviously pushed the issue of contextual relevance into the center of biblical text interpretation and text appropriation in which the African voice has as yet not been digested. The author does not shy away from crucial issues that pose new challenges to an agenda of greater inclusive biblical interpretation ${ }^{33}$ (emphasis is mine).

However, a few reviews do disagree completely with the African transformational method by asking questions pertinently about the role of "subjectivity" in its biblical interpretation. The latter is sensed in Sneed's

Proverbs on Poverty, by Lechion Peter Kimilike, BCT 6/2 (2010): 31.1-31.3, online: https://novaojs.newcastle.edu.au/ojsbct/index.php/bct/article/viewFile/316/299. Cf. Grant LeMarquand, review of Poverty in the Book of Proverbs: African Transformational Hermeneutic of Proverbs on Poverty, by Lechion Peter Kimilike, BNA 27 (2011): 10-11. Cf. Ernest C. Lucas, Proverbs (Cambridge: William B. Eerdmans Publishing Company, 2015), 311-314. Cf. Holter, "The 'Poor' in Ancient Israel," 209-221.

31 Cf. Lucas, Proverbs, 311-314.

32 Lucas, Proverbs, 314.

33 Nel, review of Poverty in the Book of Proverbs (by Lechion Peter Kimilike), https://www.bookreviews.org/bookdetail.asp?TitleId=6641. 
doubts in the method as being "blatantly subjective" and "eisegesis," and the method's "most fatal flaw" of unauthenticated assumptions with respect to the growing acceptability of the popular origin of the OT Proverbs. ${ }^{34} \mathrm{Nel}$ adds about the method the

all too easy assumption that African societies based their moral principles on the existence of a Supreme Being (22). There is no conclusive evidence that belief in a Supreme Deity underlies morality in all African communities. ${ }^{35}$

Hence, such arguments appear to indicate to be still unconsciously holding fast to the subjectivity embedded in the traditional Western perspective and the complicity of the Western elitist avoidance orientation in proving the practicality of their biblical interpretation, especially, in its teaching failure to ask fundamental questions of poverty in society. Such critics should take an earlier caution by Brueggemann that:

We are now able to see that what has passed as objective, universal knowledge has in fact been the interested claim of the dominant voices who were able to pose their view and gain either assent or docile acceptance from those whose interest the claim did not serve. Objectivity is in fact one more practice of ideology that presents interest in covert form as an established fact. ${ }^{36}$

The preceding idea is an unconsciously fatal flaw in the Euro-American biblical interpretations as exemplified by Sneed's continued consideration that

[t]hough poverty was probably simply an intellectual problem (theodicy) for them, its existence meant that the sages who composed proverbs were forced to explain how a just God could allow it to exist. They sensed that poverty and justice did not add up. ${ }^{37}$

Some notable reviews of the promulgated African transformational hermeneutic of proverbs are citations in articles related to research developments in the discipline of biblical studies. ${ }^{38}$ Whereas Nel's review notes the meaninglessness of trying to defend positions between textual meaning and textual appropriation models in biblical interpretation instead argues to look for

34 Cf. Sneed, review of Poverty in the Book of Proverbs (by Lechion Peter Kimilike).

35 Nel, review of Poverty in the Book of Proverbs (by Lechion Peter Kimilike).

36 Walter Brueggemann, Texts under Negotiation: The Bible and Post-Modern Imagination (London: SCM, 1993), 9.

37 Sneed, review of Poverty in the Book of Proverbs (by Lechion Peter Kimilike).

38 Cf. Holter, "Role of Historical-Critical Methodology," 377-389. Cf. Holter, "The 'Poor' in Ancient Israel," 209-221; cf. Nel, “Trends," 460-471. 
convergences based on commonalities and differences. ${ }^{39}$ Actually this is the aspect being argued by transformational approaches based on the African unitive view of reality which considers even differences in the context of their contribution to the dynamics of the whole. ${ }^{40}$

Holter writing on the "'poor' in ancient Israel - and in contemporary African biblical studies" also notes the tension ${ }^{41}$ termed by Nel as a "clash of perspectives." 42 His conclusion asserts confidently that with the new input from Africa of textual appropriation on contemporary struggles for justice and human dignity as an "academic discipline, biblical studies is about to become more than simply a provider of textual and historical raw material; it has its own agenda!" Obviously biblical scholars have to heed the call "to participate in the building of a better world."

In my opinion, the preceding position gives us an opportunity to proceed to face squarely the practicality of our biblical interpretations in the face of the prevalent poverty-driven injustice. It is an undeniable fact as a starting point that a just God of abundance cannot allow poverty to exist. In particularly from Africa, Tanzanian point of view the stand was and still noted clearly very early 1960s that:

[U]nless the Church, its members and its organisations express God's love for man [sic] by involvement and leadership in constructive protest against the present human conditions, then it will become identified with injustice and persecution... if the Church is not part of our poverty and part of our struggle against poverty and injustice, then it is not part of us. ${ }^{43}$

A similar stand is a quote from Nelson Mandela, an anti-apartheid activist and former president of the Republic of South Africa, who says:

Overcoming poverty is not a task of charity; it is an act of justice. Like Slavery and Apartheid, poverty is not natural. It is man-made and can be overcome and eradicated by the actions of human beings. Sometimes it falls on a generation to be great. YOU can be that great generation. Let your greatness blossom. ${ }^{44}$

39 Cf. Nel, "Trends," 469.

40 Cf. Kimilike, Poverty, 166-167.

41 Cf. Holter, "The 'Poor' in Ancient Israel," 219.

42 Cf. Nel, "Trends," 460-471.

43 Julius Kambarage Nyerere, Freedom and Development (London: Oxford University Press, 1973), 214-220.

44 Nelson Mandela Quotes Quotable Quotes https://www.goodreads.com/quotes/136955-overcoming-poverty-is-not-a-task-ofcharity-it-is 
From the African political gurus cited above arise two perplexing and problematic questions that cannot be easily silenced: What is the position of our churches and by extension biblical scholars on the issues that confront the poor and poverty in society? Why do the poor find it so difficult to get justice? Hence this generation is challenged.

It is after all a spiritual value to strive for the eradication of poverty, to share wealth and education with one's fellow humans, to enjoy human culture after mouths are fed. History and religion should be no threat to material upliftment, but a means to it. A serious threat is their downscaling and abolishment. ${ }^{45}$

\section{RE-READING THE POVERTY PROVERBS AS PROVERBIAL LITERATURE}

Proverbs as an art form of literature by nature is generally a greatly manoeuvrable art form. The application of proverbs serves as opportunities for the listeners to reflect, and create innovative insights and awareness of a fresh social reality without necessarily fragmenting the entities. The quality of manoeuvrability denies the reader or hearer to have a literal application of a proverb. But rather it brings with it a necessary condition of meditation and an unpacking of the proverb in order to discern the fundamental life value or teaching that was meant by it. In other words, proverbs, riddles, enigmas and parables are all similar types of word pictures that present food for thought and reflections. The referred dynamic process of thinking and reflecting is being translated into action and applied to one's life and behaviour. And it is the way one perceives the world within and without that leads to wisdom and understanding in the expected good or happy life ultimate.

Taking in mind the above explanation I consider that even in the proverbs of OT Proverbs literature interpretation has to consider the arrangement of the proverbs as not being haphazard. The sages' use of wordplays, key words, alliterations, content, and other devices in the ordering and editing of the diverse proverbs was for the purpose of helping the reader or hearer in the use of participative dynamic thinking and reflection process in evolving of a transforming consensus interpretation of a relative proverb or group of proverbs. Hence the proverb's double purpose: convey truth and simultaneously train the reader/hearer in a thinking mode by encouraging the critical skills for identification of behaviour patterns and the association of them with their resultant effects.

With respect to the above transforming possibilities I concur with suggestions that such an understanding is important when dealing with

45 Eben Scheffler, Politics in Ancient Israel (Pretoria: Biblia, 2001), 11. 
proverbs relating to wealth and poverty. ${ }^{46}$ The argument here is based on noting the scholars' tendency

to read them too literally, not paying attention to the way that many are used figuratively as part of the sages' rhetoric on this subject. How is the reader to know when a proverb should be read figuratively? Sometimes it is because a literal meaning does not make sense.

This is also noted by Murphy suggesting that no sooner the student engaging with Proverbs ambiguities is "forced to question the serenity and optimism of the book." 47

\section{E REASONS FOR THE CHOICE OF PROVERBS 31:1-9}

Leadership is the biggest challenge facing the African continent today. Thus, firstly, to that effect the choice of the Lemuel's mother oracle or admonition to the King text (Prov 31:1-9) is based on the two perplexing and notorious questions raised earlier with respect to leadership. The concern takes into account the constitutive element of social justice in a dynamic process of thinking and handling of the poor and poverty in a society's transmission of leadership/kingship transformative values. Hence, every new crop of leaders/kings has to attend to specially designed leadership training before taking office. Such activity has to be undertaken by dedicated institutions of governance that can focus on the important noble task. In this oracle, the training institution is exemplified by the queen mother representing the parental instructive guidance to children in the family (cf. Prov 1:8; 31:26, 28). By extension the training refers to civil education that focuses on providing ethical foundations needed to raise good citizens.

Secondly, the choice of the Prov 31:1-9 relates to the terms appearing in the poem concerning social justice and poverty which have been variously mentioned in the text, such as, "perversion of rights," "afflicted," "bitter distress," "misery," "destitute," "judge righteously," "defend the rights," "needy," "women," "poverty" and "poor." These terms from an African perspective refer to the multifaceted nature of poverty that subjects households, communities and society at large to a state of powerlessness, hopelessness, and a lack of self-esteem, confidence and integrity. It leads to a situation of a multidimensional vicious circle of perpetual vulnerability an intergeneration inheritance regardless of race, age and ethnicity unless there are realistic and workable interventions to address the situation.

Thirdly, the choice of the text is on the literal sense of the central verses Prov 31:6-7 "Give beer to those who are perishing, wine to those who are in

46 Cf. Lucas, Proverbs, 294.

47 Roland E. Murphy, Proverbs (Nashville: Thomas Nelson Publishers, 1998), xxv. 
anguish; let them drink and forget their poverty and remember their misery no more." From an African perspective, the literal understanding of this set of proverbs does not make sense as it tends to be an absurdity that needs to be looked into correctly.

\section{F RE-READING PROVERBS 31:1-9: TRANSFORMATION LEADERSHIP TRAINING}

\section{Textual and introductory remarks}

Proverbs 31:1-9 as read in the REB is one of the two distinct self-contained poems constituting Prov 31, namely, "The words of Lemuel" (vv. 1-9) and "The woman of worthy" (vv. 10-31). The latter poem, however, seems to have received much more attention than the former in biblical scholarship. Even in commentaries Prov 31:1-9 is not taken to be part and parcel of Prov 31:10-31 despite of the resemblances noted of references to women, the term "worth" for king and woman, and the command to speak out on behalf of the needy. ${ }^{48}$ The reason for the scanty attention to Prov 31:1-9 in my opinion may be centred on Prov 31:6-7 whose literal sense does question the ethos being envisaged for the leadership proposed act.

Since there seems to be a consensus among biblical scholars that there is no Israelite or Judean king named Lemuel, then Lucas uses the presence of Aramaism terminology bar (son) in v. 2 and mélākîn (kings) in v. 3 to infer that Lemuel is foreigner per se. However, the foreignness element in OT proverbs has to be treated with caution because in my opinion it may lead to denying Israelite's cultural originality with dire consequences. ${ }^{49}$ For the purpose of this paper I concur with Lucas that the lack of definite article athnah makes the Hebrew word maśś $̂$ a common noun meaning "burden" or "oracle" rather than a place name a reading that has been adopted in various translations such as the NRSV and REB. ${ }^{50}$ Hence the lamed before Lemuel in 31:1 can be interpreted "either as possessive ('of'), or as the indirect object of the teaching of the queen mother." 51 When used as an indirect object of the teaching of Lemuel's mother, then a possible reading of the lamed would be "the words for," or the "words dedicated to" that gives the mentioned translation to go well with the direct speech admonition the queen mother gives to her son in vv. 2-9.

This text being a proverbial poem a possible connection of the name Lemuel to Solomon is a matter of guesswork. Lemuel, like Agur (Prov 30),

48 Cf. Madipoane Masenya, How Worthy is the Woman of Worth: Re-Reading Proverbs 31:10-31 in African-South Africa (New York: Peter Lang, 2004), 85-86.

49 Cf. Kimilike, Poverty, 38-45.

50 Cf. Lucas, Proverbs, 193.

51 Murphy, Proverbs, 239. 
could well be a pseudonym-but not necessarily for Solomon. ${ }^{52}$ Perhaps it was a nickname for this king used particularly by his mother. In my opinion from an African perspective it might be a real given dedication name by the queen mother if we take into account the meaning of the name, that is, Lemuel "devoted to God" or "belonging to God" (v. 4). It is important to note that in Prov 31:1-3, Lemuel's mother repeatedly uses the word "son" referring to him as a son of her own womb and son of her vows confirming her exercise of divine maternal authority that is nothing less than that of the father (Prov 1:8).

All African names similar to Hebrew names have meaning because they mark occasions of birth or describe the expected personality of the individuals as the naming includes offering of prayers for long life and prosperity. Taking the meaning of the name Lemuel it bears a religious feeling and experience "that another religious being has been born into profoundly religious community and religious world." 53 Hence in Africa, rulers are not simply political heads: they are mystical and religious heads, the divine symbol of their people's health and welfare. They are divine or sacral rulers, the shadow or reflection of God's rule in the universe. As such Africans regard them highly as some communities give them highly elevated positions and titles such as "saviour," "protector," "child of God," "Lord of earth and life" et cetera. ${ }^{54}$ This aspect gives the holistic nature of the proverbial material.

Briefly the immediate literary context of Prov $31: 1-9$ is related thematically to the numerical admonitions to the king in the preceding Prov 30 by mentioning problem women - the adulteress and odious woman (Prov 30:20, 23)—while Lemuel's mother here warns her son against giving his strength to women, by which kings are destroyed (31:3). In this case the former explicates the characters of women forewarned in the later leading to kings' accrual of concubines as well as adulterous and infidelity in marriage, both of which could ruin rulers. Destruction may be through disease, through the squandering of national wealth and distraction from state duties, or subjecting themselves to indignity, blackmail, vengeful plotting or palace intrigue between wives trying to exalt themselves and their sons, and through moral degradation leading to other vices. ${ }^{55}$

52 Cf. "The Words of King Lemuel from his Mother (Proverbs 31:1-9)," Beyond Today, http://bible.ucg.org/bible-commentary/Proverbs/Words-of-King-Lemuel-fromhis-mother/.

53 John S. Mbiti, African Religions and Philosophy (Nairobi: Heinemann, 1989), 118-120. This can also be inferred from Hannah's prayer in 1 Sam 1:11 and 28:50.

54 Cf. Mbiti, African Religions, 182.

55 Cf. "The Words of King Lemuel from his Mother (Proverbs 31:1-9)," Beyond Today, http://bible.ucg.org/bible-commentary/Proverbs/Words-of-King-Lemuel-fromhis-mother/. 
More so the above warning is strongly emphasised in traditional African society whereby the sanctity of marriage and family in which it is considered to be a religious duty and responsibility for everyone because it is a uniting point of the living-dead, living and future generations. ${ }^{56}$ Departure from the norm can cause disharmony in the holistic community and lead to misfortunes and punishment. This consideration is important because in African traditional society the

king's personal shortcomings and his strengths are not only his own but those of the whole population. Because they affect both the population and the land, the king has to ensure that he is always in good physical, ritual and spiritual condition. ${ }^{57}$

Although there is no clear transition between the two poems, Prov 31:1-9 is also related to the following poem of Prov 31:10-31 by having been purposely juxtaposed to establish final parental (motherly) instruction. This aspect is noted through similar lexical and thematic links to women, the term "worth" for king and woman, and the command to speak out on behalf of the needy. However, unlike Prov 30 that explicates the negative characters of women to be avoided Prov 31:10-31 expounds through the positive characters of woman worth of marriage as central to the transformational leadership personal and public life cohesiveness, non-contradictoriness and personal discipline reflection demands of Prov 31:1-9. ${ }^{58}$ The latter can lead to a good life for the community.

Most of the commentaries and studies on Prov 31:1-9 have variously titled the poem as "The Teaching of King Lemuel's Mother,"59 "The Words of King Lemuel,"60 "The Words of Lemuel,"61 "The Sayings of Lemuel's Mother," et cetera with negligible differences between them showing an agreement of its self-containment, completeness of sense and unity. This aspect has even led some to consider the independent circulation of the poem like Prov 31:10-31. For the purpose of analysis, the introduction to the poem is covered by the superscription of v. 1 and the mother's strong call to attention for the advice she intends to give on all the divine duties of king and what to do and avoid for ensuring adequate good governance. The referred introductory contents have been discussed above.

56 Cf. Mbiti, African Religions, 148.

57 Magesa, African Religion, 225.

58 Cf. James Ian Harris, "The King as Public Servant: Towards an Ethic of Public Leadership Based on Virtues Suggested in the Wisdom Literature of the Older Testament," JTSA 113 (2002): 61-73.

59 Cf. The Harper Collins Study Bible: New Revised Standard Version, with the Apocryphal/Deuterocanonical books, Wayne A. Meeks (gen. ed.) and Jouette M. Basler et al (assoc. eds.), New York: HarperCollins Publishers, 1993.

60 Cf. Lucas, Proverbs, 193.

61 Cf. Murphy, Proverbs, 239. 
In my opinion from my Bena Tanzanian perspective the teachings of the poem can be viewed as transformative when divided into five parts: v. 1-2 textual and introductory remarks, v. 3 - sustainability of personal strength and power of rulers, vv. 4-5 - transparency and accountability in public and corporate life of rulers, vv. 6-7 - self-reliance policies, and vv. 8-9- social justice advocacy. These aspects are vital and crucial in the operation of a dynamic systematic traditional African world view ensuring an enduring survival of good social, economic, political and religious life pattern. Hence, from "an early age the youth were given moral formation towards acquiring habits, attitudes, beliefs, skills, and motives that enabled them to fit into the community as mature and responsible adults." ${ }^{62}$ Similarly is clear, too, in ancient Israel the process of teaching was important and values, guidelines and laws were also taught from one generation to another through parental teaching. ${ }^{63}$

\section{Verse 3 - Sustainability of personal strength and power of rulers}

"Do not give your strength to women, your ways to those who destroy kings."

Commentators have noted about the manoeuvrings associated with ways that cause ruin exemplified in sexual pleasure on the royal power moral sensibility destruction. The Biblical case for this aspect concerns "David's adultery with Bathsheba (2 Sam 11-12), and its effects of a king's royalty to Yahweh is seen in the influence of Solomon's harem" 64 with his 700 wives and 300 concubines (1 Kgs 11:1-8). It should be noted that the word translated with "strength" here can also be used in reference to physical powers as in "vigour" or "stamina" the reason other terms such as "use of money" or squandering of wealth in pursuit of pleasure, luxuriant, corrupt and immoral lifestyle that eventually destroys mind, body, and spirit can be included. ${ }^{65}$ However, considering the proverbial language employed one has to go beyond the guarding against women as object of men's pleasure as the only lesson being delivered here. I do concur with the

62 Christine Wanjiru Gichure, Ethics for Africa Today: An Introduction to Business Ethics (Nairobi: Paulines Publications Africa, 2008), 30. Whereas Lucas, Proverbs, 194, finds there are two admonitions that appear earlier in proverbs of sexual restraint (cf. Prov 5:1-23; 6:20-35; 7:1-27) and drunkenness restraint (cf. Prov 20:1; 23:19-21, 29-35).

${ }^{63}$ Michael V. Fox, "The Social Location of the Book of Proverbs," in Texts, Temples, and Traditions: Attribute to Menahem Haran, ed. Michael V. Fox, et al. (Winona Lake: Eisebrauns, 1996), 232.

64 Lucas, Proverbs, 194.

65 Cf. The GNB translates this in a concrete way: "Do not use all your energy on sex and all your money on women; they have destroyed kings." 
feminist's reading of wisdom literature suspicion on the termed "women" in ancient Israel as indication of powerful forces to reckon with as argued: ${ }^{66}$

Women are not chattel in Proverbs, nor are they simply sexual objects; they are persons of intelligence and will, who, from the male's point of view expressed here, either make [cf. Woman Wisdom, good wife and Woman of Worth] or break [cf. loose woman and other/strange woman] a man. ${ }^{67}$

From the above citation, then, the presence of the term "women" in Prov 31:3 is used with a sense of synonymous conditions: that is, the situation of the cultural, social, economic and political marginalisation of women is part and parcel of poverty. For that matter, the terminology "women" in v. 3 can be referred to as a "vestige of the voice of the oppressed still residing in the Hebrew Scriptures." 68 Hence the proverb has to be treated as a voice of resistance against the leadership's exploitation of women using a language that does not embarrass by shaming the powerful. It takes into high regard the humanity of the oppressor - ubuntu to speak of rulers' detrimental actions to the interests of women. Therefore Prov 31:3 in a sense offers an accessible public voice (women scheming for influence for themselves and their children?) to those who are constrained to silence. As might be expected, this voice seems to be mostly used by women, since their opportunities to speak out are limited by patriarchal traditional systems. In other words it is men's wickedness and indulgence injustices that derogate the status of women because God did not create harlots. In Bena the saying that would be stated in the riddle: Pali mugogolo pivindi ivembela umutima gwa munu - Translation: "There is a bowed old person at the stream crying to have a human liver" (Explanation: The riddle refers to a trap used to catch innocent animals/birds in the field. Teaching a person that one has always to be careful because there are many evil people who have plans to do harm as they do not wish well the success one is making in life).

\section{Verses 4-5 - Transparency and accountability in public and corporate life of rulers}

"It is not for kings, O Lemuel, it is not for kings to drink wine, or for rulers to take strong drink, lest they drink and forget what has been decreed and pervert the rights of all the afflicted."

66 For a critical analysis of the other or foreign woman, cf. Masenya, How Worthy, 94.

67 Phyllis A. Bird, "Images of Woman in the Book of Proverbs," in Religion and Sexism: Images of Woman in the Jewish and Christian Traditions, ed. Rosemary Radford Ruether (New York: Simon and Schuster, 1974), 60.

68 Cf. Mark Sneed, "Israelite Concern for the Alien, Orphan, and Widow: Altruism or Ideology?” ZAW 111 (1999): 498-507. 
In these verses commentators single out the warning about inebriation or intoxication as the enemy of royal justice by mentioning dangers inherent in alcoholic drinks noted in Prov 20:1 and Isa 28:7. ${ }^{69}$ Chiastic schema is proposed when these two verses are extended to include vv. 6-7. However, I find there is not enough support to the preceding idea because the arrangement does not seem to justify the relationship between the prohibition and injunction to drink. Rather it seems that vv. 4-5 give an explanation of the drunkenness metaphor as an exemplification of situations that give themselves to moral vices (cf. Isa 5:11-12; Prov 23:29-35). Hence, the reason for the preceding suggestion is that such metaphorical drunkenness situations are about power and authority corruptive tendencies that blind the leaders' right understanding, leading to failure in proper discernment, right interpretation, sound and just judgments or decision-making.

The drunkenness metaphor is obvious in the Bena proverb: Ilidzogolo peligalile, lisemwa idza ilimasimula - Translation: "When the cock is drunk it forgets about the eagle" (Explanation: This proverb is an admonition to people who get out of one circumstance and forget about it. In life, it is always good for one to remember that whatever threatens one's life never goes away, regardless of one's circumstances. The advice is that one should always be on the alert). Or in the following metaphorical beer proverb: Uwugumbi pewingye humutwe uluhala lwinyilila kwivala - Translation: "When beer enters, the brain moves out" (Explanation: There are many kinds of intoxicants, such as status, possessions or knowledge, if it gets into the head, it corrupts the mind and this is weakness).

From the above discussion, one can rightly infer that the existence of the degraded "women" and "those who destroy kings" is envisioned in Prov 31:45. It is ironic to the king who is supposed to be the manifestation of the divine among the people (Prov 29:14) ${ }^{70}$ becomes involved in wicked behaviours that eventually fire back, that is, bring disharmony, disunity and chaos in society. The preceding point is clear, as in Prov 31:3 from an African context where justice is key in "both the ability to lead and the validity of any leadership depend greatly on whether the leader is fair and just"71 to the people regardless of status or gender.

69 Cf. Murphy, Proverbs, 241.

70 Cf. Katharine J. Dell, "The King in the Wisdom Literature," in King and Messiah in Israel and the Ancient Near East: Proceedings of the Oxford Old Testament Seminar (Sheffield: Sheffield Academic Publishers, 1998), 179. Cf. Bruce K. Waltke, The Book of Proverbs: Chapters 15-31 (Rapids: William B Eerdmans, 2005), 441442.

71 Magesa, African Religion, 246. 


\section{Verses 6-7 - Self-reliance policies}

"Give strong drink to the one who is perishing, and wine to those in bitter distress;

let them drink and forget their poverty and remember their misery no more."

In my opinion, this set of proverbial verses has at least received some attention among commentators because of its paradoxical nature leading to several hypotheses on its moral content. The latter content from a more literal reading of the set of verses has suggested a "cynical,"72 "sarcastic"73 or some merciful relief, palliative or anaesthetic function to the unfortunate. ${ }^{74}$ In this case the latter suggestion implies the commentators are right to see poverty as an anomaly.

However, their suggestions emphasise a kind of spiritualised poverty solution that works against the noble efforts to empower the people. Rather the terms are insistent on enabling the poor to survive the harsh conditions of poverty by

focusing mainly on spiritual condition of the individual persons, but it also deprives believers of a holistic salvation because sexism, classist, and racist structures of domination are allowed to remain intact without any significant social critique. ${ }^{75}$

As a result such superfluous terms lead to the prevalent teaching of prosperity or the rhetoric of miracles that do nothing to encourage productivity or a work ethos. Such an approach is far from being transformational or even liberation theology rather it enslaves even more because it leads into total dependency on charity from benefactors. Hence in this respect I certainly concur with those who find it difficult to justify the literal reading when there are proverbs referring to excesses, such as Prov 20:1; 23:20-21;29-35 that emphasize to the contrary. ${ }^{76}$ Therefore there is a need to look into an alternative reading.

Thus, as pointed out earlier from an African perspective the Prov 31:6-7 literal understanding of does not make sense at all; hence, a complete absurdity is noted because its moral practicality is impossible. Among the Bena they would say: Avanu avinywa uwugimbi uhugadza amahodzi, valufike ulwa kuva amahodzi galumanyile uhuyengela pakyanya ndevye ilifulo ilya uwugimbi pe

72 Cf. Roger N. Whybray, Proverbs, NCB (London: Marshal Pickering, 1994), 424.

73 Cf. Lucas, Proverbs, 194.

74 Cf. Murphy, Proverbs, 240-241.

75 Madipoane Masenya, "The Bible and Poverty in African Pentecostal Christianity: The BOSADI (Womanhood) Approach," in Religion and Poverty: Pan-African Perspectives, ed. Peter Paris (London: Duke University Press, 2009), 152-165.

76 Cf. Harris, "The King as Public Servant," 61-73. 
vwituta - Translation: "People who drink beer to drown their sorrowful thoughts, should know that sorrows know how to float just like the froth above the beer" (Explanation: Those who drink the local brew blow away the foam above the beer in order to drink the liquid but after taking the sip the froth returns to cover the liquid. Thus, one is advised against taking measures that have nothing to do with the issue at hand). Thus for the proverbial application of beer Prov 31:6-7 it is important to have a clear previous knowledge of the morals and characteristics behaviour of human beings in the context of its usage in the African traditional society. ${ }^{77}$ Drinking beer, namely, uwugimbi made from corn or uwulasi taped from bamboo ${ }^{78}$ in Bena society is multifunctional because it is an integral part of their lives tied to their social, religious, ritual and economic life. That means beer is more than just a beverage or food among the Bena including many indigenous African societies; it is a critical component of their social, economic and political wellbeing.

Firstly, the consumption of beer to the Bena is treated as a social activity rather than as an individual act to reinforce unity among them by strengthening their social networks. In the preceding sense beer also plays an essential role in the establishment of social obligations for strength, happiness and hospitality.

Secondly, beer has an important economic aspect. In order to gather a work party, beer is essential; without beer, it can be impossible to bring people together to cooperate on the task at hand such as planting and harvesting their crops. Among the Bena migove that is "cooperative work" is one of the most important reasons for making beer. They prefer to hoe the farm, plant and harvest their crops, build a house for a relative or neighbour, with cooperative labour from the relatives or village community, and beer is part of the refreshment for communal work. The beer acts as a binding force among individuals, families and communities and reinforces the social and economic

\footnotetext{
77 Cf. Kimilike, Poverty, 69-70.
}

78 The Bena valleys were planted with bamboo and farm boundaries were planted with bamboo. It is said when they immigrated they travelled with a bamboo root to plant wherever they settled. Thus, wherever you find a bamboo plant it indicates the presence of a Bena. The issue of beer is similar to other ethnics in Africa as Joshua S. Madumulla, Proverbs and Sayings: Theory and Practice (Dar es Salaam: Institute of Kiswahili Research, University of Dar es Salaam, 1995), 168-169, says that to most West Africans it went that 'where there is kola there is life,' but to the Mhehe it was, "where there is drink (pombe), there is life." That is why some Wahehe would jokingly say that the first thing they were made to taste at their birth was local brew. The expression bears the original significance of manifesting the perpetually flowing fountain of pombe. This is portrayed by the image of the calabash full of pombe which froths and spills over, continuously, running down the sides in thin rivulets. A Mhehe, sitting before such a tempting sight, would recite the expression above (or even the whole stanza), praising the limitless supply of beer. 
obligations and reciprocity that cooperative works inculcate especially work ethos of self-reliance. ${ }^{79}$

However it should be noted that among the Bena;

Power of the ethnic group was vested in the mutwa such that he also symbolized overall integration of the society. The mutwa has to provide security... exercised both ritual and administrative powers over the wider community as well as over their own individual families. The wellbeing of the people and land was thought to depend on the mutwa's physical health and his observance of special rituals. $^{80}$

The special rituals related to instilling the qualities of a powerful leader. The reason he was addressed Adze Senga ("adze" means come; "senga" means cow as a symbol of power and wealth). The implication of the greeting is that "Now that all cattle (wealth) belong to your highness, you have no need to desire wealth. Direct your attention to your subjects". ${ }^{81}$ Thus in political terms the Bena chief is obliged to mobilise such above described dynamic and valued resources of solidarity, humaneness, the spirit of sharing and the technique of survival crystallized in their culture of everyday life to confront human suffering, adversities and poverty in society. Among the Bena the egalitarian principle dominates where wealth is considered to be a common good. Anybody who goes against the preceding orientation is considered as wicked and cannot win against the community. ${ }^{82}$

From the preceding discussion of the Bena, African perspective it can be inferred that Prov 31:6-7 is prophetic in clearly directing the leadership ability to share and give power to the society because poverty eradication by nature as was in traditional African society was a shared responsibility (cf. Also Ps 72:14, 12-14; Prov 16:10-15).

\section{$5 \quad$ Verses 8-9 - Social Justice Advocacy}

"Open your mouth for the mute, for the rights of all who are destitute.

Open your mouth, judge righteously, defend the rights of the poor and needy."

In my opinion the above concluding verses of the poem with the use of the action verbs "open your mouth," "judge" and "defend" bear a prophetic seal to the "emphasis on social responsibility of the monarch" 83 arguing due diligence

79 Cf. Kiwovele, Malezi na Elimu, 23, 40.

80 Nyagava, History of the Bena, 56-57.

81 Nyagava, History of the Bena, 56-57.

82 Cf. Kiwovele, Malezi na Elimu, 73.

83 Murphy, Proverbs, 241. 
Kimilike, "Poverty Context in Proverbs," OTE 31/1 (2018): 135-163

towards upholding social justice ideals in terms of preceding issues of v. 3 sustainability of personal strength and power of rulers, vv. 4-5 - transparency and accountability in public and corporate life of rulers, and vv. 6-7 - selfreliance policies. The resultant of this sustained leadership effort "recognizes that ultimate stability comes from the divine patron of the king who looks out for the poor" 84 as in Prov 29:14. ${ }^{85}$ It is both the leadership and society's moral responsibility to correct wrong behaviours among them otherwise they risk morally ruining their own community as such.

More so, is the relevancy of the transformative approach of learning taken by the queen mother as a parent to deliver the lesson to his son that clearly demonstrates the essence of participatory formation in inculcating a self-reliant characteristic in the learner. The latter was central in the Tanzania's education for self-reliance promulgated under the Ujamaa ideology when it emphasised for sustainable development had to ensure that the

Education provided must therefore encourage the development in each citizen of three things; an enquiring mind; an ability to learn from what others do, and reject or adapt it to his [sic] own needs; and a basic confidence in his [sic] own position as a free and equal member of the society, who values others and is valued by them for what he [sic] does and not for what he [sic] obtains. ${ }^{86}$

The above educational approach is also more evident in Prov 31:1-9 significantly might enable people to take risks and thus act as a real transformative force.

\section{G TRANSFORMATIVE LEADERSHIP AND COMMUNITY TRAINING TANZANIAN CASE CODE OF CONDUCT FOR PUBLIC SERVICE}

Indeed, various policies and strategies have to recognize morality as a crucial pillar for good governance and paramount for inclusive growth and sustainable national development in the country. Hence, Prov 31:1-9 calls for leaders' sustainable personal and public discipline, transparency, accountability, clear self-reliance policies and advocacy of their community. The poem's call in my opinion models a transformative metaphor that can be transferred to modern age. In the text it reflects similar challenges our society in Tanzania is facing with respect to poverty eradication together with ignorance and diseases.

84 Richard J. Clifford, Proverbs: A Commentary (Louisville: Westminster John Knox, 1999), 253.

85 Cf. Kimilike, Poverty, 236-263, for a detailed and relevant critical analysis of political situations concerning poverty.

86 Julius K. Nyerere, "Education for Self-Reliance," in Nyerere on Education, ed. Elieshi Lema, Marjorie Mbilinyi, and Rakesh Rajani (Dar es Salaam: HakiElimu, 2004), 67-88. 
Since Tanzania's independence in 1961 in the families and communities we have experienced prevalence of immoral and corrupt individuals reflected in poor service delivery, conflict of interest, misuse of power, theft and embezzlement of public resources, gender discrimination, acquisition of illegal property, corruption, favouritism, nepotism, non-adherence to the rule of law, rules and regulations, unfair decisions, lack of patriotism, and non-adherence to professional ethics. This explains the reason for the Government's priority on institutionalization of various codes of conduct for public service as extra efforts needed to effectively address unethical leadership and service.

The first phase government under Nyerere established a leadership code emanating from its Ujamaa ideology based on similar issues envisioned in Prov 31:1-9. The Ujamaa society envisions were based on three principles:

equality and respect for human dignity; sharing of the resources which we produced by our efforts; work by everyone and exploitation by none. We have set out these ideas clearly in the National Ethic; and in the Arusha Declaration and earlier documents we have outlined the principles and policies we intend to follow. ${ }^{87}$

Its effectiveness was through various training institutions starting with the children pioneer guilds (chipukizi) in primary schools, youth leagues, militia and national service military training for all youth and the national leadership college for those selected to head various public institutions ${ }^{88}$ This vision is at the heart of the admonition given to the king in Prov 31:1-9 as analysed above. The former leadership code of conduct or National Ethic and its institutions were abolished in early 1990s to pave way for the introduction of multiparty politics.

Thus, from the third phase government of Tanzania there has been drawn and instituted a code of conduct for public service that every public servant has to sign as commitment to upholding it although without prior training. Such move by itself is good sign for the need of transformation in public service that will be conducive to the intended middle income economic development of the country by 2025 . On one hand content-wise is laudable as it tries to tap basic human needs, values and emotions with the aim of inculcating them into the fundamental integrity skills of public service. Understandably the Tanzanian code of ethics and conduct for public service aims to have public servants relate meaningfully to the people they serve. The code is based on the 1977 Constitution of the United Republic of Tanzania Article $132^{89}$ and the

\footnotetext{
87 Nyerere, "Education," 67-88.

88 Such institutional training aspect is exemplified by the parental role played by Lemuel's mother in Prov 31:1-9.

89 Constitution of the United Republic of Tanzania, 1977.
} 
Ethics of Public Leaders Regulations Act 13 of $1995^{90}$ wanting high ethical standards leading to improved humaneness, transparency, morality, accountability and strengthened people's confidence in government service. This current initiative, however, is lacking vision of a nationhood that is at the heart of the admonition given to the king in Prov 31:1-9 as analysed above.

The lack of vision is a serious issue as recently a former Prime Minister Joseph Warioba has rightly pointed out that Tanzanians are yet to decide on the kind of nation they want to build arguing that the

indecisiveness is caused by the fact that the nation is yet to have citizenry which believes that all human beings are equal, who hate such vices as corruption and injustice. These are our major problems and we must find their redress ... the nation currently is seeing the principles founded by Julius Nyerere unimplemented and ignored. ${ }^{91}$

In my opinion, in addition to the preceding deficiency, the lack of training institutions weakens the levels of implementation of the current code of conduct for public service. And it creates a room for other stakeholders such as religious organisations to complement the Government's effort with training.

\section{H CONCLUSION}

Generally, Prov 31:1-9 is about honesty, accountability, pursuit of excellence, loyalty, integrity and responsible citizenship. It is about encouraging the application of societal "virtues" and seeking to institute principles of right behaviour that may serve as guides for individuals and groups. In brief, the poem is about how individuals should live within a community and suggests aspects that lead to the development of transformative leadership and community.

- Respect for others - All people in society have to be treated with dignity and respect, not as ends in themselves rather than as means to their own ends. This means they are all human beings who have equal worth and value in God and society.

- Service to others - Priority should be on community participation in order to nurture cooperation and teamwork.

- Justice for others - Every citizen has a co-responsibility to ensure that transparency, justice and fairness are central parts of their decision making regarding their lives and livelihood.

90 The Public Leaders Code of Ethics Act No. 13 of 1995 (Cap.398), United Republic of Tanzania.

91 Khalifa Said, "Tanzanians Undecided on Nation's Path: Warioba," The Citizen, 27 August 2017, online: http://www.thecitizen.co.tz/News/Tanzanians-undecided-onnation-s-path--Warioba/1840340-4072640-11 yijikz/index.html. 
- Honesty towards others - All people have to exercise openness and honesty to increase trust and build the leader-follower relationship.

- Public leader simply means any person holding or invested with the capacity to influence others, that is, in the family, clan, kinship, schools, colleges, community and nation at large should be models of integrity.

Therefore, the emphasis is on the integrity of both the leaders and community as the basic ingredient to national development as abundant resources without good leadership and people's critical awareness would not lead to development. Therefore, if there is to be any development in African countries transformational mind-sets must prevail in all sectors, that is, in politics, in economics and in our social life. With collaborative efforts from all stakeholders, participation of families and households of the entire community in the public and private sectors, including voluntary associations and religious institutions to undertake national campaigns, including teaching morality as a compulsory subject in schools, colleges and universities, hence, Africa with integrity is possible.

\section{BIBLIOGRAPHY}

Bird, Phyllis A. "Images of Woman in the Book of Proverbs." Pages 41-60 in Religion and Sexism: Images of Woman in the Jewish and Christian Traditions. Edited by Rosemary Radford Ruether. New York: Simon and Schuster, 1974.

Brueggemann, Walter. Texts under Negotiation: The Bible and Post-Modern Imagination. London: SCM, 1993.

Clifford, Richard J. Proverbs: A Commentary. Louisville: Westminster John Knox, 1999.

Davis, Ellen F. Scripture, Culture and Agriculture: An Agrarian Reading of the Bible. New York: Cambridge University Press, 2009.

Dell, Katharine J. "The King in the Wisdom Literature." Pages 163-186 in King and Messiah in Israel and the Ancient Near East: Proceedings of the Oxford Old Testament Seminar. Sheffield: Sheffield Academic Publishers, 1998. . Review of Poverty in the Book of Proverbs: African Transformational Hermeneutic of Proverbs on Poverty, by Lechion Peter Kimilike. JSOT 33/5 (2009): 156.

Eggert, Johanna. Njia Ndefu ya Shule Kuanzia katika Nyanda za Juu Kusini. Halle: Propstei Halle-Naumburg, 2004.

Fox, Michael V. "The Social Location of the book of Proverbs." Pages 227-239 in Texts, Temples, and Traditions: Attribute to Menahem Haran. Edited by Michael V. Fox, Victor Avigdor Hurowitz, Avi M. Hurvitz, Michael L. Klein, Baruch J. Schwartz, and Nili Shupak. Winona Lake: Eisebrauns, 1996.

Gichure, Christine Wanjiru. Ethics for Africa Today: An Introduction to Business Ethics. Nairobi: Paulines Publications Africa, 2008.

Harris, James Ian. "The King as Public Servant: Towards an Ethic of Public Leadership Based on Virtues Suggested in the Wisdom Literature of the Older Testament." JTSA 113 (2002): 61-73. 
Holter, Knut. "The Role of Historical-Critical Methodology in African Old Testament Studies," OTE 24/2 (2011): 377-389. . "The 'Poor' in Ancient Israel - and in Contemporary African Biblical Studies." MSt (2016): 209-221.

Jones, Edgar. Proverbs and Ecclesiastes: Introduction and Commentary. London: SCM, 1961.

Kimilike, Lechion Peter. "Using African Proverbial Folklore to Understand the Holistic Poverty Eradication Framework in the Book of Proverbs." OTE 19/2 (2006): 405-417.

. "The Poor Are Not Us!': An Exploration into the Transforming Possibilities of Old Testament and African Proverbs on Poverty." OTE 19/2 (2006): 418-428. . "After God Creates, Humankind Recreates: Reflections on the Teaching on Work as Contained in the Hebrew Bible and African Proverbs." AfTJ 29/2 (2006): 4-21. . Poverty in the Book of Proverbs: An African Transformational Hermeneutic of Proverbs on Poverty. New York: Peter Lang, 2008.

Kiwovele, Judah Bernard Matata. Malezi na Elimu ya Kiinjili katika Nchi Inayoendelea Tanzania: Mchango wa Mazungumzo ya Tamaduni Mbalimbali za Makanisa ya Kiinjili. Arusha: Makumira Publications, 2011.

Kobia, Samuel M. The Courage to Hope: A Challenge for Churches in Africa. Nairobi: Acton, 2003.

LeMarquand, Grant. Review of Poverty in the Book of Proverbs: African Transformational Hermeneutic of Proverbs on Poverty, by Lechion Peter Kimilike. BNA 27 (2011): 10-11.

Levy, Amir. "Second-Order Planned Change: Definition and Conceptualization." ODyn 15/1 (1986): 5-17, 19-23.

Lucas, Ernest C. Proverbs. Cambridge: William B. Eerdmans Publishing Company, 2015.

Madumulla, Joshua S. Proverbs and Sayings: Theory and Practice. Dar es Salaam: Institute of Kiswahili Research, University of Dar es Salaam, 1995.

Magesa, Laurenti. African Religion: The Moral Traditions of Abundant Life. Nairobi: Paulines Publications Africa, 1998. . Christian Ethics in Africa. Nairobi: Acton Publishers, 2002. . Anatomy of Inculturation: Transforming the Church in Africa. Maryknoll: Orbis Books, 2004.

Masenya, Madipoane. "The Bible and Poverty in African Pentecostal Christianity: The BOSADI (Womanhood) Approach." Pages 152-165 in Religion and Poverty: Pan-African Perspectives. Edited by Peter Paris. London: Duke University Press, 2009. https://doi.org/10.1215/9780822392309-008

. How Worthy is the Woman of Worth: Re-Reading Proverbs 31:10-31 in African-South Africa. New York: Peter Lang, 2004.

Mazrui, Ali A. and Alamin M. Mazrui. Swahili State and Society: The Political Economy of an African Language. Nairobi: East African Education Publishers, 1995.

Mbiti, John S. African Religions and Philosophy. Nairobi: Heinemann, 1989.

McKane, William. Proverbs: A New Approach. London: SCM, 1970. 
Mosha, R. Sambuli. The Heartbeat of Indigenous Africa: A Study of Chagga

Educational System. New York: Garland, 2000.

Mumford, W. Bryant. "Hehe-Bena-Sangu Peoples Of East Africa." AmAn 36/2

(1934): 203-222. https://doi.org/10.1525/aa.1934.36.2.02a00060

Murphy, Roland E. Proverbs. Nashville: Thomas Nelson Publishers, 1998.

Nel, Philip J. Review of Poverty in the Book of Proverbs: African Transformational

Hermeneutic of Proverbs on Poverty, by Lechion Peter Kimilike.

https://www.bookreviews.org/bookdetail.asp?TitleId=6641.

. "Trends in Wisdom Research: A Perspective from the African Continent."

Scriptura 111 (2012): 460-471. https://doi.org/10.7833/111-0-28

Nelson Mandela Quotes Quotable Quotes,

https://www.goodreads.com/quotes/136955-overcoming-poverty-is-not-a-task-of-

charity-it-is

Ngunangwa, Ndembwela H. "The Content of the Indigenous Curriculum of

Education: Case Study: The School (of Aristocracy) (Vanyikongo) Among the

Wabena of Tanzania." PhD diss., Pittsburgh University, 1986.

Nyagava, Seth. A History of the Bena to 1914. Songea: Peramiho Printing Press, 2000.

Nyerere, Julius K. Freedom and Development. London: Oxford University Press, 1973.

. Man and Development. Dar es Salaam: Oxford University Press, 1974.

"Education for Self-Reliance." Pages 67-88 in Nyerere on Education.

Edited by Elieshi Lema, Marjorie Mbilinyi, and Rakesh Rajani. Dar es Salaam:

HakiElimu, 2004.

Otwell, John H. And Sarah Laughed: The Status of Women in the Old Testament. Philadelphia: Westminster, 1977.

Said, Khalifa. "Tanzanians Undecided on Nation's Path: Warioba." The Citizen, 27

August 2017. Online: http://www.thecitizen.co.tz/News/Tanzanians-undecidedon-nation-s-path--Warioba/1840340-4072640-11yijikz/index.html.

Scheffler, Eben. Politics in Ancient Israel. Pretoria: Biblia, 2001.

Sneed, Mark. "The Class Culture in Proverbs: Eliminating Stereotypes." SJOT 10/2

(1996): 296-308. https://doi.org/10.1080/09018329608585098

. "Israelite Concern for the Alien, Orphan, and Widow: Altruism or

Ideology?” ZAW 111 (1999): 498-507. https://doi.org/10.1515/zatw.1999.111. $\underline{4.498}$

. Review of Poverty in the Book of Proverbs: African Transformational

Hermeneutic of Proverbs on Poverty, by Lechion Peter Kimilike. BCT 6/2

(2010): 31.1-31.3. Online: https://novaojs.newcastle.edu.au/ojsbct/index.php /bct/article/viewFile/316/299.

Strandenes, Thor. "Missiology at the School of Mission and Theology, Stavanger." SMT 94/4 (2006): 469-492.

Swartz, Marc J. "Bases for Political Compliance in Bena Villages.” Pages 89-108 in Political Anthropology. Edited by Marc J. Swartz, Victor Turner, and Arthur Tuden. Chicago: Aldine, 1966.

https://antropologiafractal.files.wordpress.com/2014/07/swartz-turner-y-tuden1966.pdf. 
The Harper Collins Study Bible: New Revised Standard Version, with the Apocryphal/Deuterocanonical books, Wayne A. Meeks (gen. ed.) and Jouette M. Basler et al (assoc. eds.), New York: HarperCollins Publishers, 1993.

Toy, Crawford Howell. A Critical and Exegetical Commentary on the Book of

Proverbs. Edinburgh: T. \& T. Clark. 1899.

Waltke, Bruce K. Book of Proverbs: Chapters 15-31. Rapids: William B Eerdmans, 2005.

Washington, Habel C. Wealth and Poverty in the Instructions of Amenemope and Hebrew Proverbs. Atlanta: Scholars Press, 1994.

Westermann, Claus. Roots of Wisdom: The Oldest Proverbs of Israel and Other Peoples. Louisville: Westminster John Knox, 1995.

Whybray, Roger N. Proverbs. NCB. London: Marshal Pickering, 1994.

"The Words of King Lemuel from his Mother (Proverbs 31:1-9)." Beyond Today. http://bible.ucg.org/bible-commentary/Proverbs/Words-of-King-Lemuel-fromhis-mother/.

Wittenberg, G. H. "The Lexical Context of the Terminology for the 'Poor' in the Book of Proverbs", Scriptura. S 2, (1986): 40-85.

Rev. Dr Peter Lechion Kimilike, Lecturer in the Department of History, Philosophy and Religious Studies at the Open University of Tanzania, Dar es Salaam, Tanzania. Email: peterlechionk@gmail.com. ORCID ID: https://orcid.org/0000-0002-1578-4608 